To cite this article: Paidakaki A. \& Parra C. (2018). "Housing for all" at the era of financialization; can (post-disaster) cities become truly socially resilient and egalitarian?. Local Environment: The International Journal of Justice and Sustainability, 23(10), 1023-1040. Published online: 12 Sept 2018.

\title{
"Housing for all" at the era of financialization; can (post-disaster) cities become truly socially resilient and egalitarian?
}

\author{
Angeliki Paidakaki and Constanza Parra \\ University of Leuven, Leuven, Belgium
}

\begin{abstract}
This paper examines the realism of the resilience ambition and process of the U.S. housing system, shedding light on its heterogeneity as well as the financialization currently acting as the driving force in real estate production. The resilience ambition leading to enhanced justice and egalitarianism is understood as the provision and maintenance of post-disaster housing for all within an institutionally diverse landscape of housing policy makers and implementers. Particular emphasis is given to the post-Katrina institutional transformations resulting from multifarious interactions between multilevel institutional structures and a diverse landscape of low-income housing policy implementers - referred as social resilience cells (SRCs) in this paper. The nature and level of these transformations determine the degree to which resilience in its heterogeneous form has been incubated in New Orleans. The paper concludes with a discussion on the macro conditions and bottom-linked governance structures under which all SRCs could be better bolstered in a post-financialization, radicalised neowelfare U.S., and which in turn create possibilities for materialising the resilience ambition.
\end{abstract}

Keywords: Institutional structures; housing; social resilience cells (SRCs); financialization; neowelfarism; egalitarian urbanity 


\section{Introduction}

This paper situates the discursive and material practices of social resilience cells (SRCs) within the post-Katrina housing (reconstruction) system in New Orleans. It focuses on the relationships between SRCs and the institutional structures of the housing system, and especially examines the territorial manifestations of state involvement in fostering social resilience of the SRCs during post-disaster recovery processes. The main question addressed in this paper is the realism of the SRCs' resilience ambition, i.e. to build egalitarian urbanities through the provision of housing for all within an institutionally diverse landscape of SRCs and institutional structures. Institutional structures are defined as established organisations, public (state agencies, governmental authorities, elected officials) and private (lobbying firms, foundations, faith-based organisations, intermediaries, financial institutions, industry associations), dedicated to the promotion of a cause or programme, in our case of affordable housing provision. Hence, they have become an important concept to analyze the macro context in which SRCs operate.

The term SRCs has emerged from the increasingly multi-dimensional understanding of resilience as a practice and process. While it initially referred to the ability of an ecosystem to resist shock (Holling 1973), the concept of resilience has travelled across disciplines and is understood today as a quality that is hetero-produced and hetero-acquired, meaning that the transformative potential of resilience, both as an ambition and as a process, is radically heterogeneous (Paidakaki and Moulaert 2017a, 2017b). This heterogeneity is manifested through various discursive and material practices which, whether alone or interactively, pre-determine and redetermine recovery trajectories in post-disaster urban contexts (Paidakaki and Moulaert 2017b).

Following the definition of SRCs developed by Paidakaki and Moulaert (2017a, 2017b), we situate SRCs within the housing system and define them as affordable housing providers or housing policy implementers, which mobilise different discursive and material practices with the aim of influencing the recovery profile of a post-disaster city. Based on these diverse practices, three types of SRCs are identified: the hegemonic pro-growth, and the alternative pro-equity and the procomaterializing. All these three types have their own transformative capacities, alliance-building strategies and political positions in the socio-institutional arenas of the housing system. They also have their own modes of interaction with powerful and influential institutional structures and state apparatuses with the aim to promote their agendas and accommodate their interests (Paidakaki and Moulaert 2017a).

In our paper, we aim to examine further this inter-organisational interaction between SRCs and institutional structures and the critical role of the latter - especially of the state 1 - in affecting final post-disaster "egalitarian" material outcomes. The questions that we seek to answer are the following: What type of functions does the multi-level state perform to socio-spatially organise and physically develop post-disaster societies? What type of apparatuses, tools and mechanisms does it mobilise to execute these functions, in particular how it supports or hampers SRCs' ambitions? To what extent do institutional path dependencies crystallize specific forms of state intervention favouring some forms of resilience at the expense of others? Under what kind of changes in governance structures can path dependencies be broken, especially in regards to allowing room for alternative forms of resilience to emerge and flourish and egalitarian urbanities to be produced? (for example, from neoliberal to neowelfare?). 
To answer these questions, we focus on the institutional characteristics, financial mechanisms, policy orientation and implementation of housing systems. More specifically, we examine the role of institutional structures within these systems in providing or disproviding productive frameworks to different SRCs in the USA in general, and post Katrina New Orleans in particular.

We structure the paper as follows. Section 1. gives some more theoretical thought to the connections between resilience, social resilience cells and the institutional complexity of the housing system. Section 2. situates the multiform state within the complex world of institutional structures and SRCs. To this end, we make use of state theories and resilience theories to examine the realism of urban egalitarianism and housing provision for all under different governance paradigms (neoliberal, neowelfare). Having conceptually clarified the notion of resilience through state concepts and the theoretical lenses of housing systems, Section 3. embarks on the empirical examination of the realism of resilience, by providing a brief overview of the role of the state in the recent highly neoliberalized, financialization-driven U.S. housing system (1990-now). This knowledge will better equip us to institutionally situate the resilience possibilities in the postKatrina USA (2005-2015). More specifically, Section 4. examines the main responses (funding mechanisms, housing programmes, policy priorities) of state agencies and other institutional structures to the Katrina housing crisis and the rebuilding challenge, with a specific focus on emerging socio-institutional transformations resulting from interactions between SRCs and institutional structures. In light of these transformations and the persistent financialization-driven realities of the current housing system, Section 5. critically examines the realism of the resilience ambition under the current neoliberal governance paradigm. Section 6., by way of conclusion, better delineates the conditions under which resilience in its highly heterogeneous form could be better sought, fostered and sustained and egalitarian urbanities be produced.

The empirical examination of the resilience ambition in the post-Katrina USA consists of qualitative research on the socio-institutional actions and inactions in response to a highly diverse and dynamic terrain of social practices mobilised by SRCs in the post-Katrina housing arena. More specifically, the first author conducted field research in New Orleans and Washington DC between March 2014 and May 2015. During these fourteen months, various types of documents on housing and disaster recovery (policy, planning, legislation, advocacy) were analyzed. The document analysis largely served as preparation for the semi-structured in-depth interviews conducted with institutional structures (state agencies at the federal, regional and local level, think tanks, lobby and intermediary groups), SRCs (for-profit and non-profit housing developers) and key interlocutors (urban specialists, local activists) involved in the post-Katrina recovery process. The interview questions were designed to reveal the various ways different institutional structures have fostered, contained or thwarted different resilience manifestations.

\section{Resilience, a post-disaster housing perspective}

Resilience has developed various "features" over its academic lifespan. First introduced as an ecological concept interpreting resilience as the capacity of a system to absorb disturbance and return to its original function in a timely manner (Holling 1973), it later developed a more sociopolitical dimension whereby resilience was understood as a dynamic socially transformative process within human systems characterised by unbalanced power relations (Davoudi et al. 2012; Goldstein 2012; Kuhlicke 2013; Mehmood 2016; Paidakaki and Moulaert 2017a, 2017b). 
To advance and enrich the scientific inquiry over the political dimension of resilience, we build upon the novel concept of SRCs and introduce socio-institutional foci and socio-political dynamics in housing systems. SRCs were introduced by Paidakaki and Moulaert (2017a, 2017b) and are divided into three widely-defined types: the hegemonic pro-growth, and the alternative pro-equity and pro-comateriliazing. Table 1. shows typical organisations representing SRCs.

More specifically, the hegemonic pro-growth SRCs are for-profit developers working closely with powerful institutions (e.g. real-estate agencies, banks, state agencies, think tanks, elected officials) with the main objective of generating and extracting market exchange values in the commodification process of housing production, including the large-scale (re)development of public affordable housing. Hence, these SRCs determine housing values mainly by the material quantity of related products, such as profit or equity, and are more likely to be involved in speculative actions. Pro-growth SRCs are less interested in (or motivated by) the social - nonmonetary - use value(s) of houses, unless public subsidies for low-and-moderate income housing production are provided (Bratt 2006; Paidakaki and Moulaert 2017a, 2017b; Turner 1978, 1980). In times of crises, hegemonic SRCs make use of the performative role of discursive practices to inform a pro-growth resilience narrative that supports capital accumulation and shapes the political responses to the rebuilding challenge.

The counter-hegemonic pro-equity SRCs, are non-profit developers most commonly working in partnership, though not exclusively, with other alternative SRCs, neighbourhood associations, civic and charity groups, foundations, intermediaries, progressive elected officials and state agencies.

Table 1. SRCs

\begin{tabular}{|c|c|c|c|}
\hline \multicolumn{4}{|c|}{ Social Resilience Cells } \\
\hline Types & Pro-growth & Pro-equity & Pro-comaterializing \\
\hline Examples & $\begin{array}{l}\text {. For-profit real estate } \\
\text { developers } \\
\text {. Real estate companies } \\
\text {. Real estate development } \\
\text { firms } \\
\text {. Triple bottom line real } \\
\text { estate development } \\
\text { companies }\end{array}$ & $\begin{array}{l}\text {. Non-profit real estate } \\
\text { developers } \\
\text {. Non-profit housing and } \\
\text { community organisations } \\
\text {. Community } \\
\text { Development } \\
\text { Corporations } \\
\text {. Faith-based community } \\
\text { developers } \\
\text {. Neighbourhood-based } \\
\text { non-profit } \\
\text { homebuilders } \\
\text {. Community-based } \\
\text { organisations } \\
\text {. (Public) Housing Rights } \\
\text { groups } \\
\text {. (Spontaneous) alliances } \\
\text { against evictions }\end{array}$ & $\begin{array}{l}\text { Community Land Trusts } \\
\text { Co-housing cooperatives } \\
\text { Self-help and self-build } \\
\text { Initiatives }\end{array}$ \\
\hline
\end{tabular}

Source: Authors, adapted from Paidakaki and Moulaert, 2017b, p. 7. 
Pro-equity SRCs aim to primarily carry forward and advocate for the (social) use values of housing produced, nevertheless, in a capitalist system (Paidakaki and Moulaert 2017a, 2017b). These SRCs bolster the use value of housing by enhancing the socio-psychological fabric of neighbourhoods, advocating for equity in the housing market and often taking political stands with the objective of altering the political balance of urban development politics (Bratt 2006; Turner 1978). Like the pro-growth SRCs, most pro-equity SRCs recognise the interpenetration of use and exchange values of housing when treated as a commodity, and hence inevitably produce exchange values (Burgess 1978). Unlike the pro-growth SRCs, most pro-equity SRCs give secondary importance to the monetary value embedded in housing as a commodity (see Turner 1978) and rather invest their profits back into the organization to sustain the delivery of their social mission. Pro-equity SRCs also tend to adopt a comprehensive approach to community development, by combining affordable housing development with initiatives that aim to preserve and improve the community relationships and quality of life. Examples of those initiatives include youth and elderly programmes, job training, urban agriculture, and crime watch programmes (Bratt 2006; Pais and Eliott 2008).

These alternative SRCs usually rely on organisations engaged in co-materializing initiatives, including the promotion of housing erection in "solidarity style" and alternative types of homeownership tenure, such as housing cooperatives and community land trusts (Paidakaki and Moulaert 2017a, 2017b). Alternative pro-comaterializing SRCs are small size community developers who overlap significantly with pro-equity SRCs (general philosophy, target populations, main competences) but rely less on public funds, develop a stronger critique against the dysfunctionalities of public low-income housing programmes and forcefully promote alternative housing tenure systems and the merits of collective building processes. In times of crises, both pro-equity and pro-comaterializing SRCs often turn to small-scale material practices to influence (post-disaster) urban processes (Paidakaki and Moulaert 2017b).

According to Paidakaki and Moulaert (2017b), the political position taken by SRCs in housing systems and socio-institutional arenas largely defines the orientation of resilience trajectories (progrowth, pro-equity, pro-comaterializing), and therefore shapes "egalitarian" socio-material outcomes. By viewing resilience through these lenses, in the next section we investigate the nature, origin, and functions of socio-institutional arenas, especially of state arenas. For this purpose, the very concept of "state" is clarified with a double aim: (1) to better situate the resilience ambitions within socio-institutional arenas; and (2) to start developing new imaginaries of a governance form - and the role of the multi-level state within it - that holds higher potential in realising the resilience ambition, namely the provision of housing for all within an institutionally diverse landscape of SRCs and institutional structures.

\section{State - resilience dialectics; some theoretical insights}

Any investigation into the role of the state in orchestrating post-disaster redevelopment experiments and promoting resilience in a fair and comprehensive way, first calls for the need to clarify the undeniably multi-faceted concept of the state (Mann 2003). What is the state? What does it do? How does it operate? What structures does it use to organise itself and society? (Clark and Dear 1984). We use state theories that approach the state as complex institutional entity, meaning an ensemble of multi-level entities which are parts of a larger socio-institutional whole 
(Clark and Dear 1984; Jessop 2005, 2007, 2015, 2016; Shaw 2003). Echoing Jessop (2005, 3), "the state...changes shape and appearance with the activities it undertakes and the scales on which it operates; the political forces acting towards it, and the circumstances in which it and they act". These political forces can either be political choices made by elected officials or class and sociopolitical struggles played out on various multi-level spatial state arenas with the aim to augment/reinforce either welfare or neoliberal state characteristics. This multiplicity of multi-level governance interactions brings to the surface a series of key features regarding the varied natures of the state, as summarised in Table 2.

Table 2. State natures.

\begin{tabular}{|l|l|}
\hline $\begin{array}{l}\text { State natures } \\
\text { ensemble }\end{array}$ & Critical observations \\
\hline $\begin{array}{l}\text { Socio-spatially } \\
\text { embedded }\end{array}$ & $\begin{array}{l}\text { States consist of almost discrete and generally disjointed apparatuses. Hence, there is no } \\
\text { singular state power, but rather various potential structural powers or capacities } \\
\text { instituted in the state as an institutional ensemble. }\end{array}$ \\
$\begin{array}{l}\text { State structures do not exist outside socio-spatial horizons but are embedded in wider } \\
\text { socio-spatial arrangements. Hence, states are spatial entities which can influence and } \\
\text { shape the geographies of socio-economic activities (e.g. infrastructure investment and } \\
\text { demographic movements) within a specific spatial and action context. }\end{array}$ \\
Symamic and & $\begin{array}{l}\text { State structures do not exist outside temporal horizons. States are dynamically evolving } \\
\text { entities which temporarily develop and consolidate specific state forms. On one hand } \\
\text { state forms are path-dependent and historically conditioned. On the other hand, they are } \\
\text { subjects of constant transformation. In this process of dynamic state (re)building, slow } \\
\text { fermentations of various kinds occur with multiple possibilities for state transformations } \\
\text { as final results. }\end{array}$ \\
$\begin{array}{l}\text { State powers are relational. Their activation depends on the structural ties developed on } \\
\text { state arenas between state structures and their encompassing political system and } \\
\text { complex web of interdependencies and social networks. Hence, the actualisation of state } \\
\text { powers depends on the action, reaction and interaction of specific social forces located } \\
\text { both within and beyond the state ensemble. These social forces pursue particular interests } \\
\text { in and through access to and control over given state capacities. }\end{array}$ \\
\hline
\end{tabular}

Source: Authors, based on Jessop, 2007, 2015; Shaw, 2003.

The multifariousness of the state signifies that various multi-level state arenas exist which may become possible entry points through which SRCs can seek fertile grounds to promote and unfold their resilience potential. Nonetheless, these various arenas are part and parcel of a temporarily consolidated larger state form. In the USA, for example, the state is characterised by an ensemble of predominantly neoliberalized apparatuses working on different administration levels with an eye towards the promotion of the business sector and its profit-oriented socio-economic activities (Gotham 2012; Gotham and Greenberg 2014). This ensemble of neoliberalized apparatuses denotes that any serious study on the macro-institutional conditions promoting resilience in the USA needs to first thoroughly examine the objective, logics and functions of the neoliberal state as a whole. Only then it is possible to start developing new, more suitable, political imaginaries for enhanced justice. 


\subsection{The neoliberal state}

The state takes a neoliberal form when it promotes regulatory capitalism, namely the promotion of a for-profit business regulatory and legislative environment within which state-backed profits can be made (Cullingworth and Caves 2013; Gotham 2012; Johnson 2011; Raco 2013). The purpose of the neoliberal state is to manage and orchestrate the transfer of public wealth, commons and resources to private hands, both for-profit and non-profit (see also Swyngedouw et al. 2002). These neoliberal "features" are further consolidated when a profit-oriented, market-mediated capitalist mode of production is discursively celebrated as "formally adequate". The most recent speculation-oriented pattern of profit accumulation - also known as financialization - has reinforced neoliberal logics (Aalbers 2008). By promising wealth accumulation through financial channels, whereby commodity production and housing provision for all are of secondary importance or rendered largely insignificant, financialization has worked to the detriment of welfare public policy decisions. When too much emphasis is put on financial gains and profit, the values, interests and motivations of pro-growth SRCs tend to be favoured at the expense of the socially sensitive, welfare-oriented pro-equity and pro-comaterializing SRCs. This inclination generates questions about social injustice regarding the allocation of rights to (re)produce the city by all, and a larger betrayal of the public interest and the civil foundation from which the state is legitimised. To respond to this injustice and betrayal, socio-political movements and emerging agents, such as alternative SRCs, have started to become the watchdogs and reminders of the state welfare mandate in their interaction with state agencies and governmental authorities. Through these interactions, various institutional "fermentations" (i.e. the genesis of new state entities and the transformation of existing ones), creating the possibility for a new (more progressive) political economy and role of the state to emerge.

\subsection{Towards neowelfarism?}

The state develops neowelfare characteristics when its primary purpose is to facilitate the mobilization of civil society for the production of social goods and services for the common good (Moulaert and Jessop 2013). As such, it becomes an enabling state ensuring that social goods and services are sufficiently provided through the fair support of a wider network of SRCs. This view of the state is important because it advances the discussion on social justice by focusing on the notion of egalitarian urbanity (Johnson 2011); it also opens up the path for larger structural changes, including a new political economy through an improved inclusion of market mechanisms with a more egalitarian allocation dynamics. Through an egalitarian urbanity lens, the social welfare state is not only the state that achieves its political objective of delivering social justice in terms of access of the individual to social services and goods. The current political challenge for the neowelfare state is to incentivize and finance with deep subsidies a diverse terrain of development actors in the most socially just way, while at the same time securing equal access to basic goods and services for all. This challenge implies that a more adequate, democratic form of the state can or is yet to be developed: one that takes the current regulatory capitalism and government by proxy (Gotham 2012) as a starting point but moves towards redistributing deep resources to a wider range of policy implementers, such as the pro-growth, pro-equity and procomaterializing SRCs. Through an invigorated civil society that co-produces the city, this paradigm shift also holds the political potential in triggering wider socio-political changes and transformations, constitutional amendments, and the introduction and consolidation of new 
complementary value systems (such as those of mutuality, reciprocity, and social solidarity) defining the new political economy.

Depending on what form it takes, the state can emerge either as a problem or as a solution to the realisation of social resilience and the production of egalitarian urbanities. In the current neoliberal form, urban egalitarianism cannot materialise when affordable housing is left to market forces and public money flows in limited amounts to meet housing needs for low-and-moderate income populations. In the pursued "radicalised"/democratized neowelfare state, nevertheless, the resilience ambition can be achieved through the liberation of all SRCs by means of equal treatment and sufficient capitalization/incentivization.

With the possibility for constant state-form fermentations in mind, we will now analyze the socioinstitutional transformations that occurred in the early and later post-Katrina recovery years, and the extent to which these transformations triggered changes in governance conditions with the potential of accommodating all SRCs in the most socially optimal way. For the purposes of this investigation, we first set the scene by briefly examining the nature of the U.S. housing systems from the early 1990s until current-day. This examination will better help us to politically and historically contextualise the resilience ambition in New Orleans post-Katrina.

\section{U.S. Housing systems (1990s-now): the rough neoliberal years}

In this section we present the recent structure of the housing system in the U.S. (1990-now) which is characterised by rough neoliberal logics with a neowelfare smile. The recent period of the U.S. housing systems is portrayed by an emerging promotion of regulated deregulation that laid the groundwork for speculation tactics. In the 1990s, the secondary mortgage market became more complex and sophisticatedly designed to satisfy the needs of investors. New financial instruments were created by a new set of housing actors that resulted in a considerable change of the underwriting criteria for mortgages (Schwartz 2015; Swack 2006). Subprime mortgage lending remained unregulated in the 1990s and in the early 2000s reinforced their growth (Schwartz 2015). The apogee of complexity in the housing finance structure was reached in the mid-2000s with the development of new types of securities devised by powerful financial forces that were based on other securities, further inflating prices and incubating speculation (see Schwartz 2015). This housing system was doomed to collapse because it was founded on the belief that housing prices would constantly increase. When housing prices started to fall, equity was obliterated and mortgages could not be refinanced (ibid). This housing bubble - a straightforward product of the era of financialization (Aalbers 2008; Pacewicz 2012) - finally burst in 2008, leading to massive foreclosures and unprecedented neighbourhood blight. To this severe destruction in the built environment and urban social fabric, the Congress responded with the establishment of the neighborhood stabilization program (NSP) as mandated by the American Recovery and Reinvestment Act of 2009. Despite this "Keynesian" move, the Congress as well as the various state apparatuses have shied away from opening up a dialogue for a new housing system to be designed. Instead, the public and political responses were limited to the introduction of temporary corrections. Thus, the secondary mortgage market remains the dominant investor in home mortgages (Schwartz 2015). 
The new era of financialization did not leave housing policy for low-income groups unaffected. As opposed to the highly centralised public housing programme legislated in the Housing Act of 1937, state and government agencies begun to authorise decentralised responsibilities already since the 1960s-1970s, and become more open towards the private sector (both for-profit and nonprofit) in the production of subsidised low-income housing. In the early 1990s, the public housing programme was replaced by the HOPE VI programme whose objective was the redevelopment of former public housing sites under the auspices of the New Urbanism (NU) design ideas. In 2010, HOPE VI was replaced by the Choice Neighborhood Initiative, similarly inspired by NU. On the financial site, the new era introduced an increasing reliance on financial instruments, namely lowincome housing tax credits (LIHTC), and the continuous attack on two major block grants benefiting low-income communities, the Community Development Block Grants (CDBG) and the HOME Investment Partnerships Program (HOME) funds. Between 2004 and 2012, federal direct expenditures for CDBG and HOME funds decreased by $28 \%$ and $60 \%$ respectively (Cullingworth and Caves 2013; Schwartz 2015). The finance model for low-income housing is now based on leveraging or patchwork financing; namely, a combination of direct subsidies administered by state and local administrative agents, and indirect expenditures (LIHTC) incorporated in the federal tax code. Given that state and local governments do not have the fund-generating capacity to meet housing needs on their own, an imposition of insufficiently funded mandates on lower levels of government largely contributes to a housing crisis and urban financial plight (Cullingworth and Caves 2013; Peacock et al. 2007; Schwartz 2015; see also Seidman 2013).

Within this new era of housing financialization, the main constraints alternative SRCs face in serving their mission of providing affordable housing to low-income communities is the shallow federal financial resources and the complex, expensive and time-consuming process of "patchwork financing" (Bratt 2006; Schwartz 2015). A lot of alternative SRCs face additional financial difficulties due to constrained access to conventional mortgage financing. In comparison to mostly well-capitalised pro-growth SRCs, alternative SRCs with limited resources seem credit-unworthy to conventional lenders. The banking system tends to display prejudice against specific borrowers, or a simple lack of knowledge on underwriting certain types of housing, such as cooperatives and land trusts (Schwartz 2015; Swack 2006). In light of serious risks of undercapitalisation and the non-realisation of the true promise of neowelfarism, alternative forms of social resilience can be alarmingly wasted.

\section{Post-Katrina New Orleans recovery}

Having provided a brief overview of the contemporary U.S. housing system as a backdrop, we now investigate the various ways institutional structures at the federal, State and local level have affected post-Katrina early and later recovery processes, and bring to light the socio-institutional transformations that have emerged from interactions of institutional structures and SRCs.

\subsection{The early recovery years (2005-2007) 5.1.1. Federal level}

When Hurricane Katrina hit New Orleans in August 2005, the Federal Emergency Management Agency (FEMA) was the public authority dealing with the management of crises, including postdisaster recovery. The transformation of FEMA in 2003, from an independent agency to one 
dependent on the military-oriented Department of Security (DHS), eroded its capacity to coordinate and deliver resources to the Katrina impacted communities (Gotham 2012; Olshansky and Johnson 2010). This incapacity led to several failures, including the early heavy reliance on trailers and mobile homes and the rejection of alternative housing proposals, all of which arguably contributed to the prolongation of the housing crisis (Gotham 2012; Olshansky and Johnson 2010; Williams and Jacobs 2011). This prolongation was further exacerbated by the hesitance of Congress in December 2005 to quickly channel supplementary CDBG Disaster Recovery (CDBGDR) funds to assist the rebuilding works in Louisiana (Olshansky and Johnson, 2010). This hesitation was justified on the basis of New Orleans' "incompetence" to deal with large sums of money. In order for Congress to ensure that the disaster funds would be sensibly spent, a recovery plan and a promise to reform city governance were required (ibid).

On the other hand, Congress was less hesitant to pass the Gulf Opportunity Zone (Go Zone) Act in December 2005 with the aim to promote tax-exemption for private activity bonds and LIHTC for the rebuilding of rental housing in the Gulf Coast (BondGraham 2011; Olshansky and Johnson 2010). According to Peck (2006), the Go Zone Act was largely the result of lobbying activities in Congress by certain conservative organisations, such as the Manhattan Institute, the American Enterprise Institute, and the Heritage Foundation. These lobby groups pushed for a series of principled solutions for recovery that favoured the work of hegemonic pro-growth SRCs by encouraging red tape reduction and promoting the private's sector's flexibility and creativity (Peck 2006).

The federal state also played an instrumental role in the demolition and redevelopment of four public housing buildings in New Orleans which suffered minimum damage by the storm. This decision was made by U.S. Department of Housing and Urban Development (HUD) and was based on the long-standing rationale that public housing is dehumanising and emblematic of urban poverty (Button and Oliver-Smith 2008), and reflects the long-standing experimentation of the U.S. government with the NU design elements (Gotham and Campanella 2011). The decision to redevelop the former public housing into mixed-income developments with HOPE VI funding provided a momentous opportunity for the pro-growth SRCs to accelerate and expand their longstanding plans for transforming public housing (BondGraham 2011), covering up real inequality.

\subsubsection{Lousiana (State) level}

Federal actions largely provided the framework for initiatives at the state level. In October 2005, the Louisiana Recovery Administration (LRA) was created by the Louisiana State government, as a business-minded agency to oversee the reconstruction effort and bypassing the authority of local elected officials. With the aid of federal-level waivers, the LRA was further able to remove income targets, public benefit requirements and public oversight from guiding recovery policies (Gotham 2015). $\$ 8$ billion on tax-exempt bonds and $\$ 170$ million in low-income housing tax credits were largely awarded to pro-growth SRCs on a first-come first-served basis without targeting communities and neighbourhoods with the greatest damage and recovery needs. The lack of sociospatial considerations by the federal and state elected officials was also evidenced by the introduction of the Road Home programme, a compensation-based housing programme favouring owners of higher-valued houses (Gotham 2015). In September 2007, the state of Louisiana took a 
first step to correct this unevenness by targeting half of its remaining tax-exempt bonds to the most heavily impacted areas (Seidman 2013). Moreover, alternative SRCs had also benefited from a pre-existing separate - but considerably smaller - pool of LIHTC exclusively accessible to nonprofits.

\subsubsection{Local level}

Critical decisions on the use of CDBG-DR funds and tax incentives were minimal at the local level and mostly rested with Louisiana state agents. According to a highly-ranked public employee in the city's community development office (personal communication, 4 September 2014), the city government was incapable of independently financing recovery due to the loss of its entire taxbase within $24 \mathrm{~h}$ of the storm. As a result, in October 2005, the city announced plans to lay off 3,000 municipal workers (Martinko et al. 2009), with the exception of police, firemen and emergency responders. The fiscal crisis was aggravated by the city's bond downgrading to junk status (Olshansky and Johnson 2010).

Nonetheless, the city government could qualify for CDBG-DR funds if a widely-accepted reconstruction plan was developed (Seidman 2013). The necessity for this plan opened the "Pandora box" from which various antagonistic socio-political forces surfaced, leading to a long and burdensome planning process. More specifically, what was observed during the first postKatrina months was the desire of powerful local actors and politicians to radically restructure the city's urban form and demographics (Olshansky and Johnson 2010). Two weeks after the storm, the Mayor of New Orleans set up the so-called "Bring New Orleans Back" (BNOB) commission, delegating a local wealthy developer, Joseph Canizaro, to be the chair of the planning committee. This committee proposed immediate recovery of those areas that suffered minimal damage and an evaluation of the feasibility for reinvestment in areas with extensive damage (ibid).

The ambiguity and controversy of those recommendations generated unease among many locally elected officials. The city council opposed the mayor-led BNOB plan and supported a neighbourhood-led counter-plan giving prominence to the flooded areas (Seidman 2013). This counteraction resulted in the discomfort of people living in the driest neighbourhoods who felt neglected. In the end, both plans were abandoned and replaced by the Unified New Orleans Plan (UNOP) which was mostly funded by the Rockefeller Foundation (Diefendorf 2009). The UNOP encouraged redevelopment in the form of clusters, prioritising the driest areas. This approach rejuvenated recovery efforts, but was nonetheless rejected by certain groups of residents who interpreted it as a denial of resources for their own severely-damaged neighbourhoods. As a result of this resistance, the plan was not actualised (Colten et al. 2008), and the city has been rebuilt to a large extent in an ad hoc, spontaneous and fragmented manner.

The BNOB plan controversy, as well as the federal decision to demolish four public housing estates, prompted a multifarious civic insurgence (Gotham and Greenberg 2014) taking the form of protests, the establishment of neighbourhood associations, and the development of neighbourhood plans. The housing deficit and the pronounced need for the rebuilding and rehabilitation of houses rapidly induced the growth or expansion of an impressive number of SRCs, notably pro-equity and pro-comaterializing2. In 2007, some of the alternative SRCs (New Orleans Area Habitat for Humanity, Providence Community Housing) formed the Greater New Orleans 
Housing Alliance3 (GNOHA) with the aim to create change in the Greater New Orleans community through public policy advocacy and public education, placing special emphasis on the needs of the most vulnerable in society.

Some institutional structures reacted quickly to this emerging local capacity. The Enterprise Community Partnership (Enterprise), a national non-profit intermediary group, set up an office in New Orleans post-Katrina and started working exclusively with professional non-profits or nonprofits owning land and property, to build affordable housing for the low-and-middle income population. According to M. Whetten, the Vice President of the Gulf Coast Enterprise Community Partners, Inc. (personal communication, 8 April 2015), the main reason for this initial exclusivity was the time constraints entrenched in the federal funds that hinder the possibilities for wider social experimentation. Since the recovery outset, Enterprise assisted alternative SRCs in accessing LIHTC in order to build rental complexes, and became their federal voice in Congress. The New Orleans Office for community development was also quick to respond to the needs of the newly emergent SRCs by enacting in 2007 the so-called "soft second mortgage programme" which was doomed necessary by the alternative SRCs for gap financing (N. Barnes, Executive Director of Jericho Road Episcopal Housing Initiative, personal communication, 4 June 2014).

In a nutshell, the early recovery years were characterised by stronger bonds between hegemonic pro-growth SRCs and well-established institutional structures, path dependencies in housing policy, as well as over-reliance on tax expenditures to finance recovery, which is certainly a tool more familiar to experienced, for-profit developers. However, some individuals and neighbourhoods in New Orleans started to organise themselves to build social resilience, with various types of SRCs and alliances emerging out of this process. In response, some embryonic new socio-institutional arrangements fostering the work of alternative SRCs are observed. In order to fully examine the extent to which the genesis of this social resilience and the new institutionalisation processes ensuring the sufficient provision of low-income housing has been incubated, we now turn our attention to the long-term socio-institutional transformation taking place over the late recovery years.

\subsection{The late recovery years (2008-2015) 5.2.1. Federal level}

The initial military approach to post-Katrina disaster planning, that directly affected housing provision in the early recovery years, was revisited with the Post-Katrina Emergency Management Reform Act of 2006. As an outcome of this Act, the National Disaster Recovery Framework (NDRF) was developed and introduced in 2009 in which social dimensions as well as a clearer division of labour between and across governmental levels were better articulated (A. Liu, Vice President and Director of the Metropolitan Policy Program at the Brookings Institute, personal communication, 23 June 2014). Under NDRF, seeds of neowelfarism can be seen, particularly through its specific celebration of the role of non-profits in disaster housing4. Speculatively, this celebration was an outcome of abundant research and advocacy efforts by think tanks based in DC who emphasised the crucial role of bottom-up groups, local knowledge, social networks, and social and community entrepreneurship in building post-disaster resilience5. Over the long-term postKatrina years, HUD gained a clearer mission assignment and stronger mandate regarding pre-andpost disaster housing recovery (Earl Randall, New Orleans Field Office Director US Department 
of Housing \& Urban Development, Personal Communication, 17 April 2015). This return and advancement of HUD was further reinforced through the introduction of the National Disaster Resilience Competition in 2014. In partnership with the Rockefeller Foundation, HUD invested around 1 billion of CDBG-DR to experiment with the resilience building policy and practice in the winning localities, including New Orleans6.

Over the late recovery years of New Orleans, federal recovery funds for the reconstruction of New Orleans were considerably reduced, displaying the limits of the shallow-pocketed neowelfarism. At the same time, two other federal initiatives inadvertently guided some of the city's rebuilding trajectories. The first initiative was the NSP taken by the U.S. Congress in 2008 to respond to the mortgage crisis and the consequent rapid decline of neighbourhoods in terms of foreclosure and abandonment. Under the NSP, competitive small grants were allocated to states, local governments, nonprofits and consortia of entities. New Orleans was awarded \$29 million to produce affordable housing units. The second initiative was the introduction in 2010 of the Choice Neighborhoods Initiative intended as a successor to the HOPE VI program. In 2011, the Housing Authority of New Orleans and the City were granted \$30.5 million to commission HRI properties, a pro-growth SRC, to transform a former public housing development (Iberville) into a mixedincome neighbourhood.

\subsubsection{Louisiana (State) level}

State agents and governmental authorities, similarly to Federal institutional structures, increasingly recognised the essential role of alternative SRCs in the rebuilding process of New Orleans. This recognition is "stamped" in various documents, including the Louisiana homeland security and emergency assistance and disaster act7 and the draft of the consolidated annual action plan for housing and community development of 20148. In 2009, the Louisiana government developed the non-profit rebuilding pilot programme9 with the promise of channelling \$20 million to non-profits. In 2015, the Louisiana Housing Corporation adopted all recommendations made by the housing alliance GNOHA on the creation of the new Homeowner Rehabilitation Program to fund the repair or reconstruction of disaster-damaged homes. The state Office of Community Development Disaster Recovery Unit also worked closely with GNOHA on the Action Plan Amendment 65 which allowed non-compliant Road Home grantees to eligibly claim interim housing expenses.

\subsubsection{Local level}

At the city level, the interactions between SRCs and institutional structures as well as the outcomes of such interactions arose in a more bold and evident manner. In 2010, the newly elected mayor announced the creation of the New Orleans Business Alliance (NOLABA), the first formal public private partnership in the city of New Orleans responsible for promoting a more "entrepreneurial" urban vision. NOLABA rebranded New Orleans as a centre for biosciences, software technology, and sustainable industries with the aim to attract and channel resources into the promoted industries (Gotham 2012). Under the new city administration, post Katrina recovery was also restrategized in various policy papers on the basis of a "place-based" approach10, holding similar logics of the cluster-based development promoted at the early recovery years. A reference to the importance of a place-based approach was also traced in an article by Kabacoff (2010), the 
influential president of the pro-growth SRC "HRI properties" and lead developer of the Iberville transformation.

The implementation of this new urban imaginary based on an "entrepreneurial" vision induced changes in the city's demographics. An influx of young educated people seeking work opportunities in the city's promoted industries caused gentrification and internal displacement, pricing out local residents (N. Barnes and M. Ripple, Partner at the Architecture firm Eskew + Dumez + Ripple: personal communications, 4 June 2014; 25 August 2016; see also Ehrenfeucht and Nelson 2013). In response to this emerging crisis of housing affordability, two bottom-up responses emerged: the creation of new pro-comaterializing SRCs promoting alternative housing tenure models, and the general invigoration of the alternative SRCs and their alliance. More specifically, in 2008, the first community land trust, CLT, (Jane Place Neighborhood Sustainability Initiative) was founded with the aim to promote the values of equity and real participation in housing systems through the introduction of new types of tenure (B. White, founding member of the Jane Place Neighborhood Sustainability Initiative, personal communication, 6 August 2014). In 2011, another major CLT, the Crescent City Community Land Trust (CCCLT) was formed. Over time, GNOHA has grown both in policy influence and membership. In 2015, the alliance reached out to few for-profit developers with a similar mindset and mission to nonprofits (affordable housing provision, community development interventions). These for-profit developers were considered an added value to GNOHA due to their realism, acquisition of a better pulse of the market, and their sway to public officials due to their proven track records of success. According to the president of GNOHA, A. Morris (personal communication, March 10, 2015), the housing movement has become more intelligent in negotiating with state agencies and more decisive in co-constructing a housing plan 11 that treats New Orleanian neighborhoods equally and introduces radical initiatives around halting gentrification (Paidakaki and Moulaert, 2017b).

In the face of newly emerging and invigorated SRCs, some institutional structures developed an interest in bolstering and further consolidating this alternative capacity. In 2015, the Greater New Orleans Foundation 12 publicly celebrated the development model of CCCLT and offered a financial award to the organisation with the last lump-sum of the Foundation's Community Revitalization Fund. In early 2014, the Foundation for Louisiana channelled TOGETHER Initiative funds to GNOHA, to initiate a community-led housing plan that would develop strategies for improving housing policies and for increasing equity in New Orleans. The social embeddedness of GNOHA's efforts were recognised and brought to the forefront by progressive elected officials, of whom a prominent example is the council member and housing activist LaToya Cantrell13. In a similar way, local state authorities responded to an increasingly recognisable capacity of alternative SRCs by making the strengthening of neighbourhood development corporations a principal goal in their Master plan14. In 2013, as disclosed by a highly-ranked public employee in the city's housing and community development office (personal communication, 4 September 2014), the City in partnership with Enterprise allocated \$150,000 of HOME funds to a selected group of non-profit housing developers.

Along the same path, the New Orleans Redevelopment authority (NORA) initiated a series of innovative and inclusive interventions in the policy areas of low-income housing and disaster recovery 15. NORA is the public authority responsible for the revitalisation of under-invested areas and the leading agent in implementing citywide recovery initiatives at the late aftermath of Katrina. 
An example of such inclusiveness was the decision of NORA to apply to HUD as a consortium with non-profit developers in order to access NSP funds. The consortium was awarded \$29 million and NORA oversaw the production of 425 affordable housing units mainly developed by nonprofits (A. Stroud, real-estate development consultant and Principle at the Urban Focus LLC Louisiana: personal communication, 12 August 2014). Enterprise was also involved in the NSP programme, as a technical assistance provider. As an outcome of this involvement, Enterprise began to develop relationships with new, less experienced non-profits. As opposed to the early years of recovery, when the central focus was the construction of large LIHTC rental multifamily properties in partnership with professional alternative SRCs, Enterprise became more aware of the local context. As a result, Enterprise started factoring two crucial realizations into their future strategies: (1) the use value New Orleanians place in home-ownership; and (2) a lot of the city's housing stock is single family. These realizations have led Enterprise to consider building more partnerships with single-family alternative SRCs and devise financial instruments better suited for these new types of development.

Pro-growth SRCs have been also explicitly acknowledged by various institutional structures, including Enterprise and local state authorities. The capacity of experienced for-profit developers in successfully competing for tax credits and other subsidies in combination with their understanding of the real-estate business have made these SRCs reliable actors in delivering necessary material outcomes. As a result, according to a highly-ranked public employee (personal communication, 4 September 2014), the city equally mobilises the for-profit forces by incentivizing them with HOME or CDBG funds to produce affordable housing. Based on these distinctive capacities of the for-profit sector, Enterprise and city authorities have also encouraged partnerships between for-profit and non-profit actors.

To sum up, the late recovery years were characterised by an overall improved governance structure in which spores of neowelfarism were seeded. This improvement not only translates into the acquisition of a more clear role of state agencies operating at different spatial scales in post-disaster recovery; it also reflects the positive disposition of state agencies and other institutional structures towards social experimentation and their increasing engagement with alternative SRCs on the ground. The role of alternative SRCs and their alliance in generating these socioinstitutional transformations towards a more socially just treatment of the non-profit housing sector has been decisive. Counter-hegemonic discourses and strategies have indeed found a more fertile ground locally, but have meanwhile failed to shake the building blocks of the housing finance system. In the words of K. Labord, the President and CEO at the Gulf Coast Housing Partnership, "it is hard to change the direction of the titanic" (personal communication, 29 August 2014). This implies that alternative SRCs, despite their increasing local prominence, have mainly worked under the macro-financial mechanisms already in place (e.g. tax credits, limited public subsidies) and have proved to be less successful in triggering larger structural changes in the U.S. housing system. State agencies, elected officials and other institutional structures have similarly limited their actions within the constraints of the given housing finance paradigm. In the absence of a substantially welfare-oriented frame, the ambitious societal goal of resilience pursued by policy makers, state agencies, elected officials and other institutional structures and SRCs, cannot be truly materialised. 


\section{Post-disaster resilience at the era of financialization; a fragile ambition?}

In this section, we provide a synthesis of the macro conditions that have bolstered and stifled the resilience potential in New Orleans, and critically examine the possibilities and the constraints for materialising resilience in the U.S. urban contexts.

\subsection{Co-created macro conditions bolstering resilience}

The flexibility and responsiveness of some institutional structures to a heterogeneous terrain of SRCs provides an important condition within which resilience was interactively bolstered in New Orleans. The federal government, for instance, recognised the importance of incorporating sociospatial specificities and local knowledge in disaster planning. By introducing the NDRF, the federal government shifted from a strong top-down approach to recovery to an improved multilevel agency coordination and interaction with external partners. Moreover, the fact that HUD has gained a firmer role in recovery mirrors a fundamental shift of the state apparatus towards better entangling the long-term community development and low-income housing mandates with disaster planning, allowing the two urban agendas to develop strategic synergies.

Partly as a result of the decentralisation promoted in the 1960s-1970s, the geographical and institutional proximity between institutional structures and SRCs based in New Orleans or in Louisiana's capital city Baton Rouge also played an important role in fostering diversity of housing actions. Due to this proximity, institutional structures such as the Louisiana Housing Corporation (LHC), NORA, Enterprise and the Louisiana Foundation, were in a better position to apprehend and respond to the distinctive advantages and inconveniences of a diverse landscape of SRCs over time. Omissions in programmes designed in the immediate aftermath of Katrina (see Road Home) were corrected, new housing programmes became more "tailor-made", and alternative housing models were discursively celebrated and financially better supported.

As a consequence of the numerous post-Katrina unmet housing needs, the emergence of alternative forms of resilience can also be traced back to a series of incentives found in the Tax Code and Federal housing programmes prior to Katrina, which facilitated mission-oriented individuals and groups to form non-profits. The Internal Revenue Code offers tax exemptions to charitable organisations 16, and separate pools dedicated for funding non-profits only in the HOME and LIHTC programmes proved to be instrumental in triggering, and to some extent maintaining, the initial grassroots action. Intermediary actors in the current U.S. housing system, such as Enterprise, have also played a significant role; notably by providing technical assistance and grants to alternative SRCs in order to survive in a finance-led housing development environment.

\subsection{Co-created macro conditions stifling resilience}

While several positive socio-institutional arrangements were in place prior to Katrina (or in its immediate aftermath) to foster resilience, a series of other structural arrangements served to counteract this. These enduring opposing forces can be traced back in the years of rough neoliberalism. The primary structural constraint is the fact that the social economy, and more specifically subsidised low-income housing, relies on unstable state support (in the form of grants and subsidies) and charitable donations. As K. Labord (personal communication, 29 August 2014) 
explains, the fact that housing supply is not capitalised on an organisation-development basis but on a transaction-focused basis, considerably prohibits non-profits to fully grow in the USA. This denotes that many non-profit developers, either pro-equity or pro-comaterializing SRCs, are de facto incapable of accessing capital markets, rendering them constantly vulnerable to undercapitalisation. The pro-growth SRCs represented by the for-profit housing industry sit more confidently in the financialization processes, including the competition for tax credits, whereas the mission-oriented non-profit industry struggles to access and leverage sufficient funding. This asymmetry of capacities among SRCs under the current paradigm brings serious risks. It implies that in the absence of constant, grave and direct state interventions and deep subsidies, the survival of alternative SRCs as well as the promotion of alternative forms of housing and the production of a sufficient affordable housing inventory are threatened (see also Davis 2006).

The realism of the resilience ambition and process can also be threatened by the current deepseated ideological and socio-political hegemonies in the U.S. decision-making structures. This hegemony mainly translates into the relevant lack of autonomy/immunity of local states to control and organise recovery processes. Higher state tiers play the most instrumental role in urban processes in the USA through their regulating standards of implementation, constitutional and legal constraints, and control in the form of administrative practices (Clark and Dear 1984). This denotes that the possibility for resilience incubation at the local level largely relies on the resources and policies determined by decisions taken in Washington DC and the influential capacity of the lobbying machine in Congress. Therefore, the resilience ambition remains at the mercy of distant political decision centres characterised by complex and multiple interactions among inter alia Congress members, large lobby firms17and industry associations18. In other words, conflicting agendas, power relations, and different levels of influential capacities among lobby actors largely define the type of "resilient actions" to be supported by federal agencies. In such governance structures, the degree to which federal decisions are locally relevant largely depends on the capacity of local SRCs and their industry associations to effectively communicate on the federal level the needs, priorities and assets of their constituents. This constraint in the current governance structure calls for an urgent deliberation on the types of governance formulations that can overcome inertia in neoliberalized housing systems, and allow room for alternative forms of resilience to emerge and flourish. In the next and final section of this paper we aim to initiate this discussion.

\section{Post-disaster resilience; a realistic possibility leading to urban egalitarianism?}

Post-disaster resilience is not only a high societal ambition but also, as testified, a tenacious politicized process. When examined through the lenses of housing systems, this paper takes an ethical position arguing that resilience in its heterogeneous form can only be realised when diverse housing needs are universally met, and alternative housing production propositions are recognised and sufficiently and continuously fostered. Hence, resilience holds hands with radicalism in housing policy. As witnessed in the case of post-Katrina New Orleans, the narrow and rigid frames provided by the financialization paradigm have thwarted such a realisation. The current pathdependent socio-structural state of the macro-economy, backed-up by the current political forces, mainly supports and maintains the dominance of the for-profit capitalist firm to the detriment of other economic forms. The absence of a radicalised neowelfare governance structure, promoting diverse economic forms (cooperative, non-profit, for-profit, private, public) and introducing and 
consolidating new complementary value systems (mutuality, reciprocity, and social solidarity), reflects the weakness of the current neoliberal governance model that is largely unstable, socially and economically unjust, and authoritarian. Without an economic foundation underpinning the values of mutuality and reciprocity, alternative SRCs can never attain the needed maturity to overcome their dependence and fragility. To avoid this oppression, the institutional conditions, governance structures and financial systems under which the resilience ambition may serve and aim for the common good need urgently to be imagined and devised.

The realisation of the resilience ambition, we argue, requires a new governance structure in which the state is committed to democratise both itself and the economy. This calls for massive social investments and fundamental legislative and (housing and tax) policy reforms, which expand alternative economic forms and enable the consolidation of the rising social economy as a major socio-economic force in society. The housing affordability problematic calls into question the current political economy and the traditional roles of the state and civil society in housing systems. The emergence of alternative SRCs and their alliances - especially during housing crises - raises the important question of what the nature of affordable housing is, and of what kinds of organisational structures, institutions and arising forces are best suited to provide the best kind of housing for people.

The answer lies at the core of egalitarian urbanities and the notion of social justice in governance processes. As we witnessed in the case of New Orleans, various state agencies and other institutional structures through their mutual and multi-level spatial interaction with different SRCs, have played a critical role in fostering to varying degrees and in various diverse ways - discursively and materially - different forms of local resilience. Nevertheless, housing deficits remain acute in New Orleans, lowincome housing production is generally vulnerable to market winds, and many alternative SRCs struggle to remain sufficiently capitalised to deliver their social missions. In light of such a bleak context, the ambition of resilience will remain fragile. To overcome such a threat, any serious and honest discussion on resilience should hold hands with another, more important, deliberation on alternative visions of the state. There is a desperate need to politicise the discussion on resilience in order to protect its policy implications from market or market-friendly institutional logics. Emphasis should be placed on the social practice of the state in the everyday procedures in which SRCs are involved to guide the heterogeneous development of cities. Such a model of governance underscores the process of effectuation (Moyersoen and Swyngedouw 2013) whereby the state apparatus becomes the partnering and liberating agent of the plurality of voices and production forces on the ground (see also Clark and Dear 1984). In this way, the housing reconstruction process becomes institutionally politicised.

A central precondition of this socio-politicised disposition and the generation of the larger transition to a radicalised neowelfare state is the constant presence of SRCs in housing systems. Furthermore, SRCs should be involved in (re)negotiation with institutional structures on the conditions (financial and planning tools, policy priorities, housing programmes) under which postdisaster urbanities can become more egalitarian. This calls for the need for the neowelfare state agencies, in their partnering role, to put their focus on the micro-physics of resilience and develop a deeper understanding of (1) the challenges, opportunities and compromises SRCs face in their struggle to remain present in housing and socio-institutional arenas; (2) the history, evolution and capacities of different SRCs; (3) the level of their embeddedness in community and their social 
engagement; (4) the geographical areas of intervention and social groups prioritised by SRCs as well as the justification for such decisions; and (5) the temporalities of resilience, and more precisely the specific, changing social needs that SRCs help to fulfil in the different phases of the post-disaster/reconstruction cycle. Institutional structures and the scientific community alike need to produce this necessary knowledge in order to further shed light on the complex spatio-temporal realities of resilience at the micro level, and the blurred connections between the micro level initiatives and the macro level institutional settings. This bottom-linked governance (re)building will better uncover the parasitic relationship between the resilience ambition and the financialization paradigm, and allow room for improved governance structures that uninterruptedly embrace diversity and aim for resilience futures that are socially relevant to all.

Notes

1. In this paper, the state is approached in its multi-level, multi-form entirety including its varied functions, agencies and bureaucratic apparatuses. State apparatuses, hence, are not examined as a unitary body but as separate yet interrelated public entities with different levels of autonomy, social and spatial foci, as well as openness to interact with other public entities and private bodies.

2. Examples of alternative SRC in post-Katrina New Orleans: Jericho Road Episcopal Housing Initiative (http://www. episcopalchurch.org/library/video/jericho-road-episcopal-housing-initiative); Broadmoor Improvement Association (http://www.broadmoorimprovement.com/); Providence Community Housing (http://www.providencecommunityhousing.org/ ; Project Homecoming (http://projecthomecoming.net/); Gulf Coast Housing Partnership (http://www.gchp.net/); New Orleans Area Habitat For Humanity (http://www.habitat-nola.org/); Rebuilding Together New Orleans (http://www.rtno.org/).

3. "The Greater New Orleans Housing Alliance is a collaborative of non-profit housing builders and community development corporations working to rebuild the housing stock available in the city of New Orleans after Hurricane Katrina devastated the city's infrastructure" (http://www.gnoha.org/main/home).

4. "Recovery Support Functions involve partners in the local, State and Tribal governments and private and nonprofit sectors not typically involved in emergency support functions but critically needed in disaster recovery. These new partners may include public and private organisations that have experience with permanent housing financing, economic development, advocacy for underserved populations and long-term community planning" (Housing Recovery Support Function: https://www.fema.gov/recovery-support-functions).

5. Mercatus Center: https://www.mercatus.org/tags/gulf-coast-recovery-project, The Brookings Institute: https://www.brookings.edu/book/resilience-and-opportunity/.

6. http://portal.hud.gov/hudportal/HUD?src=/press/press_releases_media_advisories/2016/HUDNo_16-006.

7. "The legislature finds the that resources of nongovernmental non-profit organisations can contribute greatly to the state's formalised framework for implementation of the requirements of this Chapter. Inclusion of the efforts of nongovernmental nonprofit organisations in the state's emergency preparedness, response, and recovery plans to the greatest extent predictable is encouraged" (http://www.legis.la.gov/Legis/Law.aspx?d=452286).

8. "A strategy to address the needs of the homeless and the at risk population, and to recognise the special needs of the various types of homeless individuals, must take into account the primary role of community based charitable organisations and voluntary programmes, alone or in partnership with local governments and public agencies, in establishing and supporting basic facilities and services for the homeless" (accessed at August 2014).

9. "In hurricane-impacted areas, successful models have been developed by CDCs and other non-profits to secure and leverage resources in order to meet the needs of homeowners to complete their rebuilding process... The state has long recognised the success of these entrepreneurial efforts and has sought to secure funding for these programmes to continue their efforts to help homeowners recover" (Action Plan Amendment 33 (First Allocation) - Nonprofit Rebuilding Pilot Program: http:/www.doa.la.gov/OCDDRU/Action\%20Plan\%20Amendments/KatrinaRita\%20First/APA33_Approved.pdf).

10. (1) A highly-ranked public employee in the city's housing and community development office (personal communication, 4 September 2014) clarified that "the place-based approach is making sure that all government resources and private resources work together. For example, if the school system aims at building new schools in one neighbourhood, and a medical operating conglomerate also targets the same neighbourhood, then the city government will direct resources to make sure that all the necessary infrastructure (i.e. streets, sewage, drainage) will support the private investment that focuses on that area. This includes housing opportunities through the adjudication of vacant 
properties by the New Orleans Redevelopment Authority (NORA)". He added: "investing resources to fix houses in areas that are not close to schools and hospitals is a not part of the strategy". (2) Place-based revitalisation strategy in the City's Blight Reduction Report: http://www.nola.gov/getattachment/Performance-and-Accountability/Initiativesand-Reports/BlightSTAT/Blight-Report_web.pdf/.

11. Housing NOLA: http://housingnola.org/main/home.

12. "With disaster funding coming to an end, we have to look at smarter ways to leverage our dollars so that more and more families in our community have access to affordable housing... By investing in the community land trust approach, we're committing to making — and keeping — homes affordable." (president and CEO of the Greater New Orleans Foundation) (http://www.gnof.org/greater-new-orleans-foundation-invests-1-million-to-supportlong-termaffordable-homes-for-new-orleans-families/).

13. LaToya Cantrell was the president of the Broadmoor Improvement Association in 2005 when the Broadmoor neighbourhood suffered from severe flooding following the post-Katrina levee failures. She emerged as a prominent activist organising the Broadmoor residents to fight against the unfair BNOB suggestions, and as a charismatic leader coordinating a participatory planning process for the recovery of the neighbourhood. Between 2012 and 2017 she represented District B in the New Orleans City Council. As a council member, LaToya worked closely with non-profit housing providers and their alliance, GNOHA to push forward changes in the local and State housing laws and programmes. On November 18, 2017, she was elected the mayor of New Orleans.

14. Vol.2 Ch.5 Neighbourhoods and Housing, http://www.nola.gov/city-planning/master-plan/.

15. "In 2014, New Orleans was officially selected to become a member of the 100 resilient cities network funded by the Rockefeller Foundation. NORA was chosen to coordinate resilience in New Orleans because it has a hand on implementation and hence, help the concept being applied on the ground" (J. Genova, Rockefeller Foundation 100 Resilient Cities Project Manager, personal communication, 15 April 2015).

16. Exemption Requirements $501 \quad$ (c) (3) Organizations: https://www.irs.gov/charities-nonprofits/charitableorganizations/exemption-requirements-section-501-c-3-organizations

17. Examples of lobby firms: http://www.vnf.com/Utility-Regulation-and-Compliance, http://www.squirepattonboggs.com/, http://bgrdc.com/.

18. Examples of national industry associations: http://nlihc.org/, http://www.enterprisecommunity.com/policyandadvocacy/issues/policy-priorities, http://www.rga.org/, http://www.nlc.org/.

\section{Funding}

This work was supported by the Fonds Wetenschappelijk Onderzoek - Vlaanderen (FWO) [grant number 83682], [11F3513N]; KU Leuven [grant number JUMO/14/016].

\section{References}

Aalbers, M. B. 2008. "The Financialization of Home and the Mortgage Market Crisis." Competition \& Change 12 (2): 148-166.

BondGraham, D. 2011. "Building the new New Orleans: Foundation and NGO Power." The Review of Black Political Economy 38 (4): 279-309.

Bratt, R. G. 2006. "Community Development Corporations: Challenges in Supporting a Right to Housing." In A Right to Housing: Foundation for a new Social Agenda, edited by R. G. Bratt, M. E. Stone, and C. W. Hartman, 340-359. Philadelphia: Temple University Press.

Burgess, R. 1978. "Petty Commodity Housing or Dweller Control? A Critique of John Turner's Views on Housing Policy." World Development 6 (9): 1105-1133. 
Button, G. V., and A. Oliver-Smith. 2008. "Disaster, Displacement and Employment: Distortion in Labor Markets." In Capitalizing on Catastrophe: The Globalization of Disaster Assistance, edited by N. Gunewardena, and M. Schuller, 123-145. Lanham, MD: Rowman Altamira.

Clark, G. L., and M. J. Dear. 1984. State Apparatus: Structures and Language of Legitimacy. Boston: Allen \& Unwin.

Colten, C. E., R. W. Kates, and S. B. Laska. 2008. "Three Years after Katrina: Lessons for Community Resilience.” Environment: Science and Policy for Sustainable Development 50 (5): $36-47$.

Cullingworth, J. B., and R. Caves. 2013. Planning in the USA: Policies, Issues, and Processes. New York: Routledge.

Davis, J. E. 2006. “Between Devolution and the Deep Blue Sea: What's a City or State to Do?” In A Right to Housing: Foundation for a New Social Agenda, edited by R. G. Bratt, M. E. Stone, and C. W. Hartman, 364-398. Philadelphia: Temple University Press.

Davoudi, S., K. Shaw, L. J. Haider, A. E. Quinlan, G. D. Peterson, C. Wilkinson, H. Fünfgeld, D. McEvoy, L. Porter, and S. Davoudi. 2012. "Resilience: A Bridging Concept or a Dead End? "Reframing" Resilience: Challenges for Planning Theory and Practice Interacting Traps: Resilience Assessment of a Pasture Management System in Northern Afghanistan Urban Resilience: What Does it Mean in Planning Practice? Resilience as a Useful Concept for Climate Change Adaptation? The Politics of Resilience for Planning: A Cautionary Note." Planning Theory \& Practice 13 (2): 299-333.

Diefendorf, J. M. 2009. "Reconstructing Devastated Cities: Europe after World War II and New Orleans after Katrina.” Journal of Urban Design 14 (3): 377-397.

Ehrenfeucht, R., and M. Nelson. 2013. "Young Professionals as Ambivalent Change Agents in New Orleans after the 2005 Hurricanes." Urban Studies 50 (4): 825-841.

Goldstein, B. E. 2012. Collaborative Resilience: Moving Through Crisis to Opportunity. Cambridge, Massachusetts: The MIT Pres.

Gotham, K. F. 2012. "Disaster, inc.: Privatization and Post-Katrina Rebuilding in New Orleans." Perspectives on Politics 10 (3): 633-646.

Gotham, K. F. 2015. "Limitations, Legacies, and Lessons: Post-Katrina Rebuilding in Retrospect and Prospect.” American Behavioral Scientist 59 (10): 1314-1326.

Gotham, K., and R. Campanella. 2011. "Coupled Vulnerability and Resilience: The Dynamics of Cross-Scale Interactions in Post-Katrina New Orleans." Ecology and Society 16 (3): 12. https://www.ecologyandsociety.org/vol16/iss3/ 
Gotham, K. F., and M. Greenberg. 2014. Crisis Cities: Disaster and Redevelopment in New York and New Orleans. New York: Oxford University Press.

Holling, C. S. 1973. "Resilience and Stability of Ecological Systems.” Annual Review of Ecology and Systematics 4 (1): 1-23.

Jessop, B. 2005. "Critical Realism and the Strategic-Relational Approach." New Formations: A Journal of Culture, Theory and Politics (56): 40-53. https://www.lwbooks.co.uk/newformations/56/critical-realism-and-the-strategic-relationalapproach

Jessop, B. 2007. State Power. Cambridge: Polity.

Jessop, B. 2015. The State: Past, Present, Future. Cambridge: John Wiley \& Sons.

Jessop, B. 2016. “Territory, Politics, Governance and Multispatial Metagovernance.” Territory, Politics, Governance 4 (1): 8-32.

Johnson, C. 2011. "Charming Accommodations: Progressive Urbanism Meets Privatization in Brad Pitt's Make It Right Foundation." In The Neoliberal Deluge: Hurricane Katrina, Late Capitalism, and the Remaking of New Orleans, edited by C. Johnson, 187-224. Minneapolis, MN: U of Minnesota Press.

Kabacoff, P. 2010. Return to Splendor. Accessed November 8, 2015. http://savecharityhospital.com/sites/default/files/Return\%20To\%20Splendor\%20\%20Pres\%20Kabacoff.pdf.

Kuhlicke, C. 2013. "Resilience: a Capacity and a Myth: Findings From an in-Depth Case Study in Disaster Management Research.” Natural Hazards 67 (1): 61-76.

Mann, M. 2003. "The Autonomous Power of the State: its Origins, Mechanisms and Results." In State/Space: a Reader, edited by N. Brenner, B. Jessop, M. Jones, and G. Macleod, 53-64. Cambridge: John Wiley \& Sons.

Martinko, M. J., D. M. Breaux, A. D. Martinez, J. Summers, and P. Harvey. 2009. "Hurricane Katrina and Attributions of Responsibility.” Organizational Dynamics 38 (1): 52-63.

Mehmood, A. 2016. “Of Resilient Places: Planning for Urban Resilience.” European Planning Studies 24 (2): 407-419.

Moulaert, F., and B. Jessop. 2013. "Theoretical Foundations for the Analysis of Socio-economic Development in Space." In Urban and Regional Development Trajectories in Contemporary Capitalism, edited by F. Martinelli, F. Moulaert and A. Novy, 18-44. London: Routledge.

Moyersoen, J., and E. Swyngedouw. 2013. "LimiteLimite: Cracks in the City, Brokering Scales and Pioneering a new Urbanity." In Spaces of Contention: Spatialities and Social Movements, edited by W. Nicholls, B. Miller, and J. Beaumont, 141-162. Farnham: Ashgate Publishing. 
Olshansky, B. R., and L. A. Johnson. 2010. Clear As Mud; Planning for the Rebuilding of New Orleans. Chicago, DC: American Planning Association Planners Press.

Pacewicz, J. 2012. "Tax Increment Financing, Economic Development Professionals and the Financialization of Urban Politics.” Socio-Economic Review 11 (3): 413-440.

Paidakaki, A., and F. Moulaert. 2017a. "Does the Post-Disaster Resilient City Really Exist? A Critical Analysis of the Heterogeneous Transformative Capacities of Housing Reconstruction'resilience Cells'." International Journal of Disaster Resilience in the Built Environment 8 (3): 275-291.

Paidakaki, A., and F. Moulaert. 2017b. "Disaster Resilience Into Which Direction(s)? Competing Discursive and Material Practices in Post-Katrina New Orleans." Housing, Theory and Society 35 (4): 432-454.

Pais, F. J., and R. J. Elliott. 2008. "Places as Recovery Machines: Vulnerability and Neighborhood Change After Major Hurricanes.” Social Forces 86 (4): 1415-1453.

Peacock, W. G., N. Dash, and Y. Zhang. 2007. "Sheltering and Housing Recovery Following Disaster." In Handbook of Disaster Research, edited by H. Rodriguez, E. Quarantelli, and R. Dynes, 258-274. New York: Springer.

Peck, J. 2006. "Liberating the City: Between New York and New Orleans.” Urban Geography 27 (8): 681-713.

Raco, M. 2013. State-led Privatisation and the Demise of the Democratic State: Welfare Reform and Localism in an Era of Regulatory Capitalism. New York: Ashgate Publishing, Ltd.

Schwartz, F. A. 2015. Housing Policy in the United States. New York: Routledge.

Seidman, K. F. 2013. Coming Home to New Orleans; Neighborhood Rebuilding After Katrina. New York: Oxford University Press.

Shaw, M. 2003. "The State of Globalization: Towards a Theory of State Transformation." In State/Space: A Reader, edited by N. Brenner, B. Jessop, M. Jones, and G. Macleod, 117-130. Cambridge: John Wiley \& Sons.

Swack, M. 2006. "Social Financing." In A Right to Housing: Foundation for a New Social Agenda, edited by R. G. Bratt, M. E.

Stone, and C. W. Hartman, 261-278. Philadelphia: Temple University Press.

Swyngedouw, E., F. Moulaert, and A. Rodriguez. 2002. "Neoliberal Urbanization in Europe: Large-Scale Urban Development Projects and the new Urban Policy." Antipode 34 (3): 542-577. 
Turner, J. 1978. "Housing in Three Dimensions: Terms of Reference for the Housing Question Redefined.” World Development 6 (9): 1135-1145.

Turner, J. 1980. "What to do about Housing — Its Part in Another development1." Habitat International 5 (1): 203-211.

Williams, S., and K. Jacobs. 2011. "Introduction: Disasters, Housing, Actuarialism and the Securitisation of Risk.” Housing Studies 26 (2): 185-195. 